\title{
PREFACE: THE LAW OF THE CORPORATE GOVERNANCE OF BANKS AND FINANCIAL INSTITUTIONS
}

The corporate governance of banks and financial institutions came under the spotlight in the wake of the global financial crisis 2008-09, the subsequent conduct scandals such as the manipulation of the London Inter-Bank Offered Rate by several UK and international banks, and other miss-selling, corruption and financial crime scandals. Although misjudgements in risk and sub-optimal corporate behaviour are not uncommon in the corporate sector, the utility and systemic risk profiles of the banking sector, in particular, are important attributes that warrant public concern with any failings in the internal governance of banks that could culminate in excessive risk-taking or sub-optimal corporate behaviour.

In this volume, we address key themes in the internal governance of banks and financial institutions that we believe are of topical interest. The law and Corporate Governance Code discussed in this volume are stated as at March 2014. In Chapter 1, Andreas Kokkinis discusses the governance structure of most widely held banks and financial institutions, and the incentives that may result in excessive risk-taking. He reveals that conventional agency-based corporate governance frameworks may be unsuitable for banks and financial institutions as they arguably do not address the governance challenges in banks and financial institutions and may indeed entail counter-productive incentives exacerbating governance problems.

In Chapter 2, Edward Walker-Arnott discusses the importance of the board as collectively managing and making key decisions in banks and financial institutions, and argues that neither company law nor financial regulation address the issue of collective responsibility and how that can be boosted to improve board stewardship. This thought-provoking chapter takes stock of recent policy discussions and proposals for legislative reforms but critically asks if new law and new provisions in governance codes are really on the right track.

In Chapter 3, John Lowry and Rod Edmunds shift the focus from collective directorial responsibility by asking whether individual directorial responsibility for banks and financial institutions could be enhanced via the application of the directors' disqualification regime. They highlight that to date it has not been applied notwithstanding some clear political pronouncements (including those of UK's Business Secretary, Dr Vince Cable) that it should be harnessed to prevent certain named directors in the UK's failed banks (RBS and HBOS in particular) from holding directorships in the immediate future. As the chapter indicates, the reasons why disqualification proceedings have not been initiated is all the more intriguing in the 
light of both the recent proposals for reforming the regime and also the introduction of the new offence of 'reckless misconduct in the management of a bank' contained in the Financial Services (Banking Reform) Act 2013.

Chapter 4 turns the attention to shareholders of banks and financial institutions and the excessive short-termism that prevails in the securities markets that characterise the nature of such shareholding. Short-termist shareholding entails behaviour such as preference for exit over voice and disengagement from monitoring, issues that have been flagged up in the Walker Report of 2009, relating to weaknesses in bank and financial institution corporate governance. Arad Reisberg critically discusses the development of short-termism as a prevalent notion in the UK securities markets and argues that although a slate of tax and corporate governance reforms (which are re-surfacing in recent reforms) may seek to change short-termist behaviour, answers to behavioural changes are far from easy and would take time to bed down.

Chapters 5-8 then address specific issues of internal governance in banks and financial institutions. In Chapter 5, Marc Moore discusses the legal and Corporate Governance Code framework for setting remuneration, and the specific controls provided in financial regulation to control excessive remuneration in the banking sector. This is an area that has seen many recent reforms at the UK and EU levels but it may be queried as to whether appropriate remuneration design can be micro-managed by legal frameworks and institutions.

Chapter 6 deals with the issue of risk management in banks and financial institutions, identified as a key problem in the global financial crisis of 2008-09. Iris Chiu discusses the failures of risk management culminating in excessive risk-taking by banks and financial institutions and how reforming the corporate governance frameworks at the highest management levels may address risk management sub-optimalities.

In Chapter 7, Iris Chiu addresses the issue of reliable and timely corporate reporting by banks and financial institutions and the role that such corporate reporting may play in incentivising market discipline. The weaknesses of corporate reporting frameworks are discussed and recent reforms are also critically examined to inquire into the objectives of corporate reporting and how that may serve as a mechanism to enhance internal governance of banks and financial institutions and external scrutiny by markets.

Chapter 8 deals with a particular issue of systems and controls in banks and financial institutions, that of instituting anti-bribery and corruption controls. Anna Donovan examines the interpretation and impact of the Bribery Act 2010 on the corporate sector and highlights particular challenges and issues faced by banks and financial institutions.

Finally, in Chapter 9 Georgina Tsagas addresses the efficacy of the UK/EU legal framework regulating the market for corporate control in the banking industry. With reference to a series of case studies, including the RBS takeover of ABN-AMRO prior to the global financial crisis, the chapter specifically examines whether the market for corporate control in the banking industry functions perversely, how this function affects and is affected by prudential concerns and whether the parties involved in an offer effectively discharge their roles respectively. The chapter highlights the consequences that may flow from a failed change in the corporate control of a bank and ultimately questions the shareholder primacy norm followed in the case of banks proposing regulatory reforms in the interests of prudence. 
This volume takes on both academic and critical perspectives in some highly topical issues in the corporate governance of banks and financial institutions. Many of its insights are also drawn from and applicable to the general corporate sector. Not only does a financial crisis give rise to reforms pertaining to the financial sector, but the mood for critical scrutiny generally of the corporate sector also paves the way for more broad-based reform at the UK and EU levels. The contributions in this volume reflect this broader context and interest.

Iris H-Y Chiu 